\title{
UJI ANTIMIKROBA EKSTRAK DAN FRAKSI TUNIKATA Didemnum molle TERHADAP PERTUMBUHAN Escherichia coli, Staphylococcus aureus, DAN Candida albicans YANG DIKOLEKSI DI SELAT LEMBEH BITUNG
}

\author{
Novia Angelica Pitoy ${ }^{1)}$, Adithya Yudistira ${ }^{1)}$, Defny Wewengkang ${ }^{1)}$ \\ ${ }^{1)}$ Program Studi Farmasi FMIPA UNSRAT Manado, 95115
}

\begin{abstract}
Tunicate Didemnum molle is a marine biota that has bioactive components that can be used as raw material for medicines. This study aims to determine the antimicrobial activity of extracts and fractions of Didemnum molle on microbial growth of Escherichia coli, Staphylococcus aureus and Candida albicans. The sample was extracted by maceration using ethanol and fractionated using, n-hexane, chloroform and methanol. Antimicrobial activity was tested using the disc diffusion test method (Kirby and Bauer). Ethanol extract of Didemnum molle inhibited the growth of microbes of Staphylococcus aureus $(8.12 \mathrm{~mm})$ and Candida albicans $(9.00 \mathrm{~mm})$. Chloroform fraction inhibited the growth of Staphylococcus aureus $(9.10 \mathrm{~mm})$, Escherichia coli $(10.00 \mathrm{~mm})$ and Candida albicans $(9.65 \mathrm{~mm})$. While the methanol fraction is only able to inhibit microbial growth of Candida albicans $(10.00 \mathrm{~mm})$. The hexane fraction shows no activity against all test microbes.
\end{abstract}

Keywords : Tunikata Didemnum molle, antimicrobial, Escherichia coli, Staphylococcus aureus, Candida albicans.

\begin{abstract}
ABSTRAK
Tunikata Didemnum molle merupakan biota laut yang memiliki komponen bioaktif yang dapat dimanfaatkan sebagai bahan baku obat-obatan. Penelitian ini bertujuan untuk mengetahui aktivitas antimikroba dari ekstrak dan fraksi tunikata Didemnum molle terhadap pertumbuhan mikroba Escherichia coli, Staphylococcus aureus dan Candida albicans. Sampel diekstraksi dengan cara maserasi menggunakan etanol dan difraksinasi menggunakan, n-heksan, kloroform dan metanol. Aktivitas antimikroba diuji menggunakan metode disc diffusion test (Kirby dan Bauer). Ekstrak etanol Didemnum molle menghambat pertumbuhan mikroba Staphylococcus aureus $(8,12 \mathrm{~mm})$ dan Candida albicans $(9,00 \mathrm{~mm})$. Fraksi kloroform menghambat pertumbuhan mikroba Staphylococcus aureus $(9,10 \mathrm{~mm})$, Escherichia coli $(10,00 \mathrm{~mm})$ dan Candida albicans $(9,65 \mathrm{~mm})$. Sementara fraksi metanol hanya mampu menghambat pertumbuhan mikroba Candida albicans (10.00 mm). Fraksi heksan tidak menunjukkan aktivitas terhadap semua mikroba uji.
\end{abstract}

Kata Kunci : Tunikata Didemnum molle, antimikroba, Escherichia coli, Staphylococcus aureus, Candida albicans. 


\section{PENDAHULUAN}

Antimikroba adalah zat-zat kimia yang dihasilkan oleh jamur dan bakteri yang memiliki kemampuan untuk menghambat pertumbuhan mikroba dan toksisitasnya terhadap manusia relative kecil. Antibiotik merupakan obat yang paling banyak digunakan pada infeksi yang disebabkan oleh bakteri dan jamur. Timbulnya resistensi telah menyebabkan kelompok antiboitik tertentu tidak lagi digunakan dalam terapi sehingga penggunaan berbagai sumber daya laut dalam pengobatan penyakit infeksi menjadi pilihan masyarakat Indonesia (Waluyo, 2005).

Indonesia terkenal dengan kekayaan alamnya yang berlimpah. Potensi yang sangat besar dalam menghasilkan senyawa-senyawa aktif yang dapat digunakan sebagai bahan baku obat-obatan berasal dari organisme laut (Thakur dan Muller, 2004). Organisme laut yang diketahui dapat menghasilkan senyawa aktif antara lain bryozoa (Sima dan Vetvicka, 2011), moluska (Kiran et al., 2014), spons (Ngantung et al., 2018), karang lunak (Kawung et al., 2017) dan tunikata (Ali and Tamilselvi, 2016).

Tunikata tergolong dalam organisme yang menempel pada terumbu karang. Tunikata banyak menghasilkan senyawa bioaktif untuk farmakologi karena dapat berasosiasi dengan mikroba fotosintetik dan mempunyai potensi molekular yang besar. Kandungan metabolit sekundernya yaitu substansi bioaktif yang sangat berguna bagi pertahanan diri organisme simbionnya (Aulia, 2011). Diketahui dari tunikata sudah ditemukan berbagai senyawa dengan bioaktivitas seperti larvasida (Rumengan, 2010), antikanker/antitumor (Wewengkang et al., 2014), antidiabetes (Li, 2012), antiinflamasi (Chan et al., 2011), antivirus (Donia et al., 2008), dan antimikroba (Wang et al., 2008). Metabolit sekunder berupa alkaloid, flavonoid dan steroid ditemukan pada tunikata Didemnum molle (Aulia, 2011).

Didemnum molle merupakan tunikata yang umum dijumpai di perairan Indonesia karena distribusi dari spesies ini tersebar di perairan Indo-Pasifik. Jenis-jenis dari suku Didemnidae merupakan jenis yang paling mendominasi di perairan dangkal tropis. Jenis tunikata dari suku Didemnidae memiliki adaptasi yang tinggi terhadap kondisi perairan dan mampu bertahan hidup pada tipe-tipe habitat (Abrar 2008).

Berdasarkan penelusuran pustaka, peneliti tertarik untuk melakukan penelitian aktivitas antimikroba dari tunikata Didemnum molle terhadap pertumbuhan Escherichia coli, Staphylococcus aureus dan Candida albicans.

\section{METODOLOGI PENELITIAN Waktu dan Tempat Penelitian}

Penelitian ini dilaksanakan pada bulan November 2018-Februari 2019 di Laboratorium Farmakognosi dan Fitokimia serta di Laboratorium Mikrobiologi Program Studi Farmasi Fakultas Matematika dan Ilmu Pengetahuan Alam Universitas Sam Ratulangi.

\section{Alat dan Bahan}

Alat yang digunakan dalam penelitian ini yaitu masker, sarung tangan, pisau, gunting, telenan, peralatan diving berupa snorkel, fins, tabung udara dan masker, kantong plastik, Erlenmeyer (Pyrex), corong pisah, gelas ukur (Pyrex), gelas kimia (Pyrex), oven, timbangan analitik (Kem), cawan petri, autoklaf (Autoclaf KT-30s), pinset, pembakar spiritus, pipet tetes, mikro tub, Laminar Air Flow (Clean Bench), lemari pendingin, incubator (N-biotek), mikropipet, jangka sorong, vial, pot salep, kamera untuk keperluan dokumentasi. 
Bahan-bahan yang digunakan yaitu tunikata Didemnum molle, bakteri uji Staphylococcus aureus, Escherichia coli, jamur uji Candida albicans, etanol 96\%, n-heksan, kloroform, metanol, ekstrak beef, pepton, $\mathrm{NaCl}$, agar, Kloramfenikol, kertas cakram, label, spidol permanen, tissue, aluminium foil, kertas saring, kapas.

\section{Jenis Penelitian}

Penelitian ini merupakan penelitian yang menggunakan metode eksperimental laboratorium.

\section{Prosedur Penelitian}

\section{Pengambilan Sampel dan Persiapan Sampel}

Sampel tunikata Didemnum molle diambil dari perairan Selat Lembeh menggunakan alat bantu (masker, tabung udara, snorkel, dan fins). Sampel dibersihkan dari kotoran yang menempel disekitarnya, difoto lalu dimasukkan kedalam plastik, kemudian dibawa ke Laboratorium Farmakognosi dan Fitokimia Program Studi Farmasi Universitas Sam Ratulangi. Sampel dipotong kecil-kecil dan diekstraksi dengan cara maserasi dengan etanol $96 \%$ lalu diberi label serta nomor sampel.

\section{Ekstraksi}

Tunikata Didemnum molle sebanyak 1195 gram diekstraksi dengan cara maserasi. Sampel di bersihkan, dipotong kecil-kecil lalu dimasukkan ke dalam botol dan direndam dengan larutan etanol 96\% sampai sampel terendam secara keseluruhan dan dibiarkan selama 24 jam. Sampel yang direndam disaring dengan menggunakan kertas saring menghasilkan filtrat 1 dan debris 1 . Debris 1 direndam dengan larutan etanol 96\% sampai sampel terendam secara keseluruhan kemudian dibiarkan selama 24 jam. Sampel tersebut disaring menggunakan kertas saring menghasilkan filtrat 2 dan debris 2. Debris 2 kemudian direndam dalam larutan etanol $96 \%$ sampai sampel terendam secara keseluruhan dan dibiarkan selama 24 jam, sampel tersebut disaring menggunakan kertas saring menghasilkan filtrat 3 dan debris 3 . Filtrat 1, 2 dan 3 dicampur menjadi satu kemudian disaring, lalu dimasukkan dalam oven sehingga didapat ekstrak kasar tunikata Didemnum molle kemudian ditimbang menggunakan timbangan analitik dan diperoleh ekstrak kasar sebanyak 2,5 gram.

\section{Fraksinasi}

Sebanyak 1,5 gram ekstrak kasar Didemnum molle dimasukkan kedalam erlenmeyer, kemudian dilarutkan dengan metanol 80\% sebanyak $100 \mathrm{~mL}$. Setelah larut, dimasukan kedalam corong pisah dan ditambahkan pelarut n-heksan sebanyak 100 mL. Setelah itu dikocok sampai homogen. Dibiarkan hingga terbentuk lapisan metanol dan lapisan n-heksan. Masing-masing lapisan ditampung dalam wadah yang berbeda. Lapisan n-heksan selanjutnya dimasukkan dalam oven lalu ditimbang dan diperoleh ekstrak fraksi nheksan sebanyak 0,095 gram.

Lapisan metanol ditambahkan akuades $100 \mathrm{~mL}$, dipartisi dengan pelarut kloroform dengan perbandingan 1:1 v/v dalam corong pisah dikocok sampai homogen. Dibiarkan hingga terbentuk dua lapisan yaitu lapisan metanol dan lapisan kloroform. Masing-masing lapisan ditampung dalam wadah yang berbeda. Lapisan kloroform selanjutnya dimasukkan dalam oven hingga kering lalu ditimbang dan diperoleh fraksi kloroform sebanyak 0,105 gram. Lapisan metanol dimasukkan kedalam oven lalu ditimbang dan diperoleh fraksi 
methanol sebanyak 1,3 gram. Ketiga fraksi yang diperoleh digunakan dalam pengujian antimikroba dan dihitung nilai rendemen dari masing-masing fraksi dengan persamaan:

\section{Sterilisasi Alat}

$$
\text { Rendemen }=\frac{\text { Berat hasil ekstrak }}{\text { Berat ekstrak awal }} \times 100 \%
$$

Alat-alat gelas yang digunakan dalam penelitian aktivitas antimikroba ini disterilkan terlebih dahulu dengan menggunakan autoklaf pada suhu $121{ }^{\circ} \mathrm{C}$ selama 15 menit, pinset dibakar dengan pembakaran di atas api langsung dan media disterilkan di autoklaf pada suhu $121{ }^{\circ} \mathrm{C}$ selama 15 menit (Ortez, 2005).

\section{Pembuatan Media Cair B1}

Ditimbang Pepton 0,5 g, ekstrak daging 0,3 g (meat extract), Natrium klorida 0,3 g dilarutkan dalam metanol sebanyak $100 \mathrm{~mL}$ menggunakan Erlenmeyer, dikocok sampai homogen. Media yang telah homogen kemudian disterilkan dengan menggunakan autoklaf pada suhu $121^{\circ} \mathrm{C}$ selama 15 menit. Dipipet $1 \mathrm{~mL}$ media cair B1, kemudian masukkan dalam tabung reaksi dan tutup dengan aluminium foil. Media cair B1 siap digunakan sebagai media kultur mikroba (Ortez, 2005).

\section{Kultur Mikroba}

Masing - masing mikroba yang sudah dikultur (Escherichia coli, Staphylococcus aureus dan Candida albicans) ditambahkan media cair B1 yang disiapkan sebelumnya sebanyak $100 \mu \mathrm{L}$ kedalam tabung reaksi yang berbeda-beda. Masing-masing tabung reaksi ditutup dengan aluminium foil dan dimasukkan kedalam inkubator selama 1x24 jam dengan suhu $37^{\circ} \mathrm{C}$.

\section{Pembuatan Kontrol Positif dan Kontrol Negatif}

Kontrol positif dalam pengujian aktivitas antimikroba ini menggunakan kloramfenikol paper disc. Kontrol negatif yang digunakan dalam penelitian ini menggunakan metanol untuk menguji apakah pelarut metanol memberikan pengaruh terhadap aktivitas daya hambat, dengan cara membuat larutan stok metanol dengan mengambil sebanyak $200 \mu \mathrm{L}$ metanol kemudian ditotolkan pada kertas cakram. Kontrol negatif digunakan sebagai pembanding.

\section{Pembuatan Larutan Uji}

Larutan uji dibuat dengan cara melarutkan ekstrak etanol Didemnum molle sebanyak $1 \mathrm{mg}$ ke dalam $200 \mu \mathrm{L}$ metanol sehingga menghasilkan konsentrasi larutan uji sebesar $250 \mu \mathrm{g} / 50 \mu \mathrm{L}$. Perlakuan yang sama dilakukan untuk fraksi n-heksan, fraksi kloroform dan fraksi metanol (Ortez, 2005).

\section{Pembuatan Media Agar B1}

Pepton 0,5 g, ekstrak daging (meat extract) 0,3 g, natrium klorida 0,3 g, nutrient agar 1,5 g dan dilarutkan dalam akuades sebanyak $100 \mathrm{~mL}$ menggunakan Erlenmeyer, dikocok sampai homogen. Media yang telah homogeny kemudian disterilkan dengan menggunakan autoklaf pada suhu $121^{\circ} \mathrm{C}$ selama 15 menit. Media agar B1 siap digunakan untuk uji aktivitas antimikroba.

\section{Pengujian Aktivitas Antimikroba}

Metode yang digunakan dalam penelitian ini yaitu metode difusi agar (disc diffusion Kirby and Bauer). Pada pengujian aktivitas antimikroba digunakan kertas cakram yang berukuran $6 \mathrm{~mm}$ dengan daya serap $50 \mu \mathrm{L}$ tiap cakram. Suspensi mikroba kemudian 
diinokulasikan ke dalam media dan dihomogenkan. Kemudian media yang telah diinokulasi mikroba dituangkan ke dalam cawan petri sebanyak $100 \mathrm{~mL}$ dan ditunggu hingga media mengeras. Sampel yang telah ditentukan konsentrasinya $(250 \mu \mathrm{g} / 50 \quad \mu \mathrm{L})$ ditotolkan pada masing-masing cakram dengan menggunakan mikropipet. Masing-masing cawan petri diberi label dan nomor sampel yang sesuai. Kertas cakram yang telah ditotolkan sampel uji tunikata Didemnum molle diletakkan ke dalam cawan petri dengan pinset lalu diinkubasi selama 1 x 24 jam (Ortez, 2005).

\section{Pengamatan dan Pengukuran Zona Bening}

Pengamatan dilakukan setelah 24 jam masa inkubasi. Daerah pada sekitaran cakram menunjukkan kepekaan mikroba terhadap antibiotik atau bahan antimikroba yang digunakan sebagai bahan uji yang dinyatakan dengan diameter zona bening. Diameter zona bening diukur dalam satuan millimeter $(\mathrm{mm})$ menggunakkan jangka sorong dengan cara diukur diameter zona bening horizontal ditambahkan dengan diameter zona bening vertikal lalu dibagi dua. Kemudian zona bening yang telah diukur, dibandingkan berdasarkan pedoman Davis dan Stout (1971).

\section{HASIL DAN PEMBAHASAN \\ Ekstraksi dan Fraksinasi}

Sampel tunikata Didemnum molle yang diambil dari perairan Selat Lembeh, dipotong kecil-kecil. Sampel dipotong kecil-kecil bertujuan untuk memperbesar ukuran sampel karena semakin luas permukaan sampel maka interaksi antara sampel dan pelarut semakin besar sehingga proses ekstraksi berjalan optimal (Ncube et al, 2008). Setelah di potong kecil-kecil sampel di masukkan kedalam wadah dan diekstraksi menggunakan metode maserasi. maserasi. Tujuan pemilihan metode maserasi karena cara pengerjaan dan peralatannya yang sederhana, tidak dilakukan pemanasan sehingga dapat mencegah terjadinya kerusakan zat aktif terhadap panas yang berlebihan. Metode maserasi sangat menguntungkan karena dengan perendaman sampel, terjadi pemecahan dinding sel karena adanya perbedaan tekanan didalam dan diluar sel sehingga metabolit sekunder dalam sitoplasma larut dalam pelarut organik (Lenny, 2006).

Maserasi dilakukan dengan menggunakan pelarut etanol 96\%. Etanol dipilih karena selektif, tidak toksik, ekonomis dan kemampuan penyariannya yang tinggi sehingga dapat menyari senyawa yang bersifat non polar sampai senyawa yang bersifat polar. Proses maserasi dilakukan 3x24 jam dengan dua kali remaserasi atau pergantian pelarut yang baru. Remaserasi dilakukan dengan tujuan untuk mendapatkan penyarian yang maksimal (Khopkar, 2008). Filtrat yang diperoleh diuapkan menggunakan oven dengan suhu $40^{\circ} \mathrm{C}$ sehingga didapat ekstrak etanol 2,5 gram.

Ekstrak yang diperoleh dari proses maserasi selanjutnya dilakukan fraksinasi dengan menggunakan tiga pelarut yang berbeda berdasarkan tingkat kepolaran. Pelarut yang digunakan yaitu n-heksan, kloroform dan metanol. Penggunaan pelarut n-heksan untuk melarutkan senyawa yang bersifat non polar, pelarut kloroform untuk melarutkan senyawa yang bersifat semi polar dan pelarut metanol untuk melarutkan senyawa yang bersifat polar.

\section{Tabel 2. Rendemen fraksi tunikata Didemnum molle}

\begin{tabular}{ccccc}
\hline No. Sampel & $\begin{array}{c}\text { Berat } \\
(\mathbf{g})\end{array}$ & $\begin{array}{c}\text { Rendemen } \\
(\boldsymbol{\%})\end{array}$ & Warna \\
\hline 1. & FH & 0,095 & 6,33 & Orange \\
\hline 2. & FK & 0,105 & 7,00 & Hitam \\
\hline 3. & FM & 1,30 & 86,67 & Putih \\
\hline
\end{tabular}


Keterangan:

FH : Fraksi n-heksan

FM : Fraksi metanol

FK : Fraksi kloroform

Pelarut yang berbeda akan melarutkan senyawa-senyawa yang berbeda karena masingmasing pelarut dapat secara selektif memisahkan kelompok kandungan kimia yang terkandung dalam sampel, sehingga didapatkan fraksi yang berbeda-beda. Hasil fraksinasi yang diperoleh, fraksi metanol memiliki rendemen yang lebih besar dibandingkan fraksi n-heksan dan fraksi kloroform. Rendemen fraksi metanol yaitu $86,67 \%$. Hal ini menunjukkan bahwa terdapat banyak komponen bioaktif yang bersifat polar dalam tunikata Didemnum molle.

\section{Uji Aktivitas Antimikroba Tunikata Didemnum molle}

Pengujian aktivitas antimikroba menggunakan metode difusi agar disc diffusion test. Metode ini dipilih karena mudah, murah dan tidak memerlukan alat khusus. Metode difusi agar adalah metode yang dilakukan dengan pengukuran dan pengamatan diameter

Tabel 3. Hasil pengujian ekstrak dan fraksi tunikata Didemnum molle terhadap mikroba uji Escherichia coli, Staphylococcus aureus dan Candida albicans.

\begin{tabular}{|c|c|c|c|c|c|c|c|}
\hline \multicolumn{8}{|c|}{ Diameter Zona Hambat (mm) } \\
\hline Mikroba & Ulangan & $\mathbf{E E}$ & FH & FK & FM & $\mathbf{K}+$ & K- \\
\hline \multirow[t]{4}{*}{ Escherichia coli } & 1 & 0 & 0 & 9,1 & 0 & \multirow[t]{4}{*}{21} & \multirow[t]{4}{*}{0} \\
\hline & 2 & 0 & 0 & 9,1 & 0 & & \\
\hline & 3 & 0 & 0 & 9,1 & 0 & & \\
\hline & Rata-rata & 0 & 0 & 9,1 & 0 & & \\
\hline \multirow[t]{4}{*}{ Staphylococcus aureus } & 1 & 8,12 & 0 & 10 & 0 & \multirow[t]{4}{*}{21,1} & \multirow[t]{4}{*}{0} \\
\hline & 2 & 8,12 & 0 & 10 & 0 & & \\
\hline & 3 & 8,12 & 0 & 10 & 0 & & \\
\hline & Rata-rata & 8,12 & 0 & 10 & 0 & & \\
\hline \multirow[t]{4}{*}{ Candida albicans } & 1 & 9 & 0 & 9,65 & 10 & \multirow[t]{4}{*}{22,1} & \multirow[t]{4}{*}{0} \\
\hline & 2 & 9 & 0 & 9,65 & 10 & & \\
\hline & 3 & 9 & 0 & 9,65 & 10 & & \\
\hline & Rata-rata & 9 & 0 & 9,65 & 10 & & \\
\hline
\end{tabular}

zona bening yang terbentuk disekitar cakram yang berisi antimikroba yang telah diinokulasi mikroba.

Penggunaan mikroba bertujuan untuk mengetahui apakah ekstrak dan fraksi tunikata Didemnum molle memiliki aktivitas antimikroba, dan untuk mengetahui spektrum dari aktivitas antimikroba Didemnum molle apakah memiliki spektrum luas yang dapat menghambat banyak jenis mikroba yaitu bakteri Gram positif dan Gram negatif, atau spektrum sempit yang hanya menghambat salah satu dari Gram positif atau negatif.

Dalam pengujian ini, hasil yang didapat yaitu adanya zona hambat disekeliling cakram berukuran $6 \mathrm{~mm}$ yang ditandai dengan zona bening, hal ini menunjukkan adanya kepekaan mikroba terhadap ekstrak atau fraksi dari tunikata Didemnum molle. Pengamatan dilakukan setelah inkubasi pada suhu $37^{\circ} \mathrm{C}$ selama 1x24 jam dengan pengulangan sebanyak tiga kali. Dilakukan pengulangan untuk lebih mengakuratkan hasil yang diperoleh. 
Keterangan :

EE : Ekstrak etanol

FH : Fraksi n-heksan

FK : Fraksi kloroform

FM : Fraksi metanol

$\mathrm{K}+\quad$ : Kontrol Positif

K- : Kontrol negatif

Dalam pengujian ini digunakan kontrol positif dan kontrol negatif. Kontrol positif berfungsi sebagai kontrol dari zat uji, dengan membandingkan diameter daerah hambat yang terbentuk (Dwijendra, 2014). Kontrol positif yang digunakan adalah kloramfenikol paper disc. Kloramfenikol memiliki aktivitas antimikroba yang lebih besar terhadap mikroba uji dibandingkan ekstrak etanol, fraksi nheksan, fraksi kloroform dan fraksi metanol. Diameter zona hambat yang dihasilkan kloramfenikol pada Escherichia coli, Staphylococcus aureus dan Candida albicans yaitu 21,10 mm, 21,00 $\mathrm{mm}$ dan 22,10 $\mathrm{mm}$. Hal ini menunjukkan bahwa kloramfenikol memiliki aktivitas antimikroba dengan spektrum luas yaitu dapat menghambat pertumbuhan bakteri gram negatif, gram positif dan jamur (Pelczar dan Chan, 1988).

Kontrol negatif berfungsi untuk mengetahui ada tidaknya pengaruh pelarut terhadap pertumbuhan mikroba uji Escherichia coli, Staphylococcus aureus, dan Candida albicans. Kontrol negatif yang digunakan yaitu metanol karena pelarut yang digunakan untuk melarutkan larutan uji yaitu metanol. Dari hasil yang diperoleh, kontrol negatif tidak memiliki daya hambat antimikroba terhadap ketiga mikroba uji. Hal ini menunjukkan bahwa aktivitas yang ditunjukkan oleh ekstrak dan fraksi tunkata Didemnum molle, murni dari senyawa yang ada dalam sampel dan bukan dari pelarut.
Dari hasil yang diperoleh, ekstrak etanol menunjukkan adanya zona bening pada Staphylococcus aureus dikategorikan sedang dengan diameter zona hambat 8,12 $\mathrm{mm}$ dan Candida albicans dikategorikan sedang dengan diameter zona hambat $9,00 \mathrm{~mm}$, sedangkan pada Escherichia coli tidak menunjukkan adanya zona bening. Hal ini menunjukkan adanya senyawa aktif yang memiliki aktivitas antimikroba berspektrum sempit karena hanya dapat menghambat pertumbuhan salah satu bakteri yaitu bakteri gram positif Staphylococcus aureus dan jamur Candida albicans, tidak menghambat pertumbuhan bakteri gram negatif Escherichia coli.

Pada fraksi kloroform, menunjukkan adanya zona bening pada Escherichia coli, Staphylococcus aureus dan Candida albicans. Masing-masing dikategorikan sedang dengan diameter zona hambat berturut-turut $9,10 \mathrm{~mm}$, 10,00 mm, dan 9,65 mm. Hal ini menunjukkan adanya senyawa aktif yang memiliki aktivitas antimikroba berspektrum luas karena dapat menghambat pertumbuhan bakteri gram negatif Escherichia coli, bakteri gram positif Staphylococcus aureus dan jamur Candida albicans.

Pada fraksi metanol, menunjukkan adanya zona bening pada Candida albicans dikategorikan sedang dengan diameter zona hambat 10,00 mm, sedangkan pada Escherichia coli dan Staphylococcus aureus tidak menunjukkan adanya zona bening. Hal ini menunjukkan adanya senyawa aktif yang memiliki aktivitas antimikroba berspektrum sempit karena hanya dapat menghambat pertumbuhan jamur Candida albicans dan tidak menghambat pertumbuhan bakteri Escherichia coli dan Staphylococcus aureus.

Pada fraksi n-heksan tidak menunjukkan adanya zona bening pada Escherichia coli, 
Staphylococcus aureus dan Candida albicans. Hal ini menunjukkan bahwa senyawa dari sampel tunikata Didemnum molle hanya bersifat semi polar dan polar bukan bersifat non-polar.

Dari hasil yang diperoleh pada ekstrak etanol dan fraksi kloroform menunjukkan bahwa bakteri Staphylococccus aureus lebih sensitif dibandingkan bakteri Escherichia coli. Hal ini disebabkan oleh perbedaan dinding sel, yaitu bakteri gram positif memiliki dinding sel yang lebih sederhana sehingga senyawa antimikroba lebih mudah masuk dalam sel (Entjang, 2003).

\section{Kesimpulan}

Berdasarkan hasil penelitian yang telah dilakukan dapat disimpulkan bahwa ekstrak etanol tunikata Didemnum molle memiliki aktivitas antimikroba terhadap pertumbuhan Staphylococcus aureus dan Candida albicans, sedangkan fraksi kloroform memiliki aktivitas antimikroba terhadap pertumbuhan Escherichia coli, Staphylococcus aureus dan Candida albicans, serta fraksi metanol memiliki aktivitas antimikroba terhadap pertumbuhan Candida albicans. Fraksi n-heksan tidak memiliki aktivitas antimikroba. Ekstrak etanol, fraksi kloroform dan fraksi metanol memiliki aktivitas antimikroba dengan ketegori sedang.

\section{Saran}

Dari hasil penelitian ini perlu dilakukan penelitian lebih lanjut mengenai senyawa aktif yang terkandung dalam tunikata Didemnum molle terlebih khusus pada fraksi kloroform.

\section{DAFTAR PUSTAKA}

Abrar, M., Manuputty, A.E.W. 2008. Inventarisasi dan Sebaran Biota
Ascidian di Terumbu Karang Perairan Berau, Kalimantan Timur: Oseanologi dan Lirnnologi di Indonesia. Lembaga Ilmu Pengetahuan Indonesia, Jakarta.

Ali, H.A.J., Tamiselvi, M. 2016. Ascidians in Coastel Water: A Comprehensif Inventory of Ascidian Fauna from the Indian Cost. Springer International Publishing, Switzerland.

Allen, G. 1996. Marine Life of Southeast Asia and Pasific. Mary Chia, Singapore.

Aulia, U.M. 2011. Eksplorasi dan Fungsi Senyawa Bioaktif Ascidian Didemnum molle sebagai Antifouling. [Skripsi]. Institut Pertanian Bogor.

Chan, S.T.S., Pearce, A.N., Januario, A.H., Page, M.J., Kaiser, M., McLaughlin, R.J., Harper, J.L., Webb, V.L., Barker, D., Copp, B.R. 2011. Antiinflammatory and Antimalarial Meroterpenoids from the New Zealand. J. Org. Chem. 76(21): 9151-6.

Davis, W. W., Stout, T.R. 1971. Disc Plate Methods of Microbiological Antibiotic Assay. Journal Microbiology. 22(4): 659-665.

Donia, M.S., Wang, B., Dunbar, D.C., Densai, P.V., Patny, A., Avery, M., Hamann, M.T. 2008. Mollamides B and C, Cyclic Hexapeptides from the Indonesian Tunicate Didemnum molle. Jurnal Natural Product. 71(6): 941-945.

Dwijendra, I., Wewengkang, D.S., Frenly, W. 2014. Aktivitas Antimikroba dan Karakterisasi Senyawa Fraksi Lamellodysidea herbacea yang Diperoleh dari Teluk Manado. Jurnal Ilmiah Farmasi. 3(4): 1-2. 
Entjang, I. 2003. Mikrobiologi dan Parasitologi untuk Akademi Keperawatan. PT Citra Aditya Bhakti, Bandung.

Kawung, N.J., Mangindaan, R.E.P., Rompas, R.M., Chasanah, E., Kapoyos, M., Abdjul, B., Januar, H.I., Fajarningsih, D., Sumagando, A. 2017. Cytotoxic Anticancer from New Compound Unsrat-sinularine of Soft Coral Sinularia sp. from Bunaken Island, Manado, Indonesia. Int. J. Drug. Dev \& Res. 9(3):1-4.

Khopkar, S.M. 2008. Konsep Dasar Kimia Analitik. UI Press, Jakarta.

Kiran, N., Siddiqui, G., Khan, A.N., Ibrar, K., Tushar, P. 2014. Extraction and Screening of Bioactive Compounds with Antimicrobial Properties from Selected Species of Mollusk and Crustacean. $J$. Clin. Cell. Immunol. 5(1) : 1-5.

Lenny, S. 2006. Senyawa Flavonoida, Fenilpropanoida dan Alkaloida. FMIPA Universitas Sumatera Utara, Medan.

Li, J.L., Xiao, B., Park, M., Yoo, E.S., Shin, S., Hong, J., Chung, H.Y., Kim, H.S., Jung, J.H. 2012. PPAR- $\gamma$ agonistic metabolites from the ascidian Herdmania momus. Jurnal Natural Product. 75(12): 2082-2087.

Ncube, N.S., Afolayan, A.J., Okoh, A.I. 2008. Assesement Techniques of Antimicrobial Properties of Natural Compounds of Plant Origin: Current Methods and Future Trends. Africa Journal of Biotechnology. 7(12): 30-32.

Ngantung, A.E.C., Bara, R.A., Sumilat, D.A. 2016. Uji Aktivitas Antibakteri dari
Spons Dictyonella funicularis dan Phyllospongia lamellosa yang diambil pada Perairan Bunaken. Jurnal Pesisir dan Laut Tropis. 2(1): 10-16.

Oretz, J. H. 2005. Disk Diffusion testing in manual of antimicrobial susceptibility testing. Marie B. coyle. American society for microbiology, Amerika.

Pelczar, M., Chan, E.C.S. 1988. Dasar-Dasar Mikrobiologi 2. Universitas Indonesia, Jakarta.

Rumengan, A.P. 2010. Uji Larvasida Nyamuk (Aedes aegypti) dari Ascidian (Didemnum molle). Jurnal Perikanan dan Kelautan. 6(2):8386.

Sima, P. dan Vetvicka, V. 2011. Bioactive substances with anti-neoplastic efficacy from marine invertebrates: Bryozoa, Mollusca, Echinodermata and Urochordata. World. J. Clin. Oncol. 2(11):362-366.

Thakur, N. L., and Muller, W. E. G. 2004. Biotechnological Potential of Marine Sponges. Jurnal Current Science. 86:1506-1512.

Waluyo, L. 2005. Mikrobiologi Umum. Penerbit Universitas Muhammadiyah Press, Malang.

Wang, W., Nam, S.J., Lee, B.C., Kang, H. 2008. Beta-carboline alkaloids from a Korean tunicate Eudistoma sp.. Jurnal Natural Product. 71(2):163-6.

Wewengkang, D.S., Sumilat, D.A., Rotinsulu, H. 2014. Sitotoksitas Ekstrak Kasar Ascidian dari Pulau Bunaken. Jurnal LPPM Bidang Sains dan Teknologi. 1(1):86-89. 